\begin{tabular}{|c|l|}
\hline Title & Greywater treatment by slanted soil system \\
\hline Author(s) & Ushijima, Ken; Ito, Kango; Ito, Ryusei; Funamizu, Naoyuki \\
\hline Citation & $\begin{array}{l}\text { Ecological Engineering, 50,62-68 } \\
\text { https://doi.org/40.1016j.ecoleng.2012.04.028 }\end{array}$ \\
\hline Issue Date & 2013-01 \\
\hline Doc URL & http://hdl.handle.net/2115/52266 \\
\hline Type & article(author version) \\
\hline File Information & EE50_62-68.pdf \\
\hline
\end{tabular}

Instructions for use 


\title{
GREYWATER TREATMENT BY SLANTED SOIL SYSTEM
}

\author{
$\underline{\text { Ken Ushijima }}^{1^{*}},{\text { Kango } \text { Ito }^{2}, \text { Ryusei Ito }}^{3}$, Naoyuki Funamizu ${ }^{4}$ \\ ${ }^{1}$ Hokkaido University, Kita13 nishi8, kita-ku, Sapporo, Hokkaido, 060- \\ 8628, Japan, uken@eng.hokudai.ac.jp. \\ Phone/fax: +81-11-706-6273 \\ ${ }^{2}$ Hokkaido University, Kita13 nishi8, kita-ku, Sapporo, Hokkaido, 060- \\ 8628 ,Japan. \\ ${ }^{3}$ Hokkaido University, Kita13 nishi8, kita-ku, Sapporo, Hokkaido, 060- \\ 8628, Japan, ryuusei@eng.hokudai.ac.jp. \\ ${ }^{4}$ Hokkaido University, Kita13 nishi8, kita-ku, Sapporo, Hokkaido, 060- \\ 8628, Japan, funamizu@eng.hokudai.ac.jp.
}

\begin{abstract}
Slanted soil system is low cost, simple system suitable for greywater treatment. Performance of the slanted soil system for greywater was evaluated in light of required water quality for irrigation reuse. Removal rate of particle $\mathrm{COD}$ and $\mathrm{BDOC}$, those may cause clogging of irrigation facility, were $94-97 \%$ and $88-89 \%$, respectively. LAS removal rates were more than $90 \%$ and final concentrations $\left(2.3-3.3 \mathrm{mg} \mathrm{L}^{-1}\right)$ were sufficiently lower than proposed target level for irrigation use $\left(8 \mathrm{mg} \mathrm{L}^{-1}\right)$. Only fine soil (1-4 mm) performed five $\log _{10}$ and $3 \log _{10}$ reductions of $E$. coli and MS2
\end{abstract}


phage, while coarse soil could not remove those pathogens. Clogging was observed in fine soil after 3-5 weeks operation, however combination of coarse soil chamber and fine soil chamber could extend it to 8 weeks. Reductions of total COD and LAS were described by $1^{\text {st }}$ order reaction model and reaction coefficient $k$ was described by equation of per area discharged rate.

Keywords: Decentralized system; water reuse; irrigation; arid zone

\section{Introduction}

Naked dry soil with no plant is difficult to keep rich soil ecosystem and it can be easily lost by wind or rain erosion. This kind of soil deterioration has considerable effect on ecosystem and agricultural productivity in arid or semi-arid zone (Lal, 1998; Visser et al. 2005). Planting through a year can reduce this soil deterioration however water limitation does not allow it in these areas. For example, in rural area of Burkina Faso, where belongs to semi-arid zone, farmers can cultivate their main farmland only rainy season. Only small garden which located shoreline of reservoir or near the well, are able to be cultivated in dry season (Ushijima et al. 2011). Distribution and time periods of available water greatly affect on agricultural activity in this area, and most of farmers are facing poverty problem due to such low productivity. On the other hand, people in this area use some amount of water for daily life even in dry season, and its 
wastewater is just disposed (Ushijima et al. 2011). Effective wastewater reuse has a potential to increase the cultivatable area and season, and it provides not only reduction of soil deterioration but also increase of productivity.

The concept of Onsite Wastewater Differentiable Treatment System (Lopez Zavala et al., 2002) can be one of suitable system for above mentioned situation. It proposes onsite treatment of greywater, urine and feces separately, in order to achieve effective resource recycling system. Separated greywater has low concentration of pollutant load (Gajurel et al. 2003) and its treatment would be easier than mixed wastewater. For example, WHO (2006) waste water reuse guideline stated that 2-7 $\log _{10}$ pathogen reduction by treatment is required for irrigation use, however separated gerywater contains $2 \log _{10}$ or more lower bacterial pathogen than mixture wastewater which WHO assumed (Ottoson \& Stenström, 2003) and therefore we are able to set 5 $\log _{10}$ as a target level of bacterial pathogen reduction for separated greywater treatment. Furthermore, if reuse purpose was focused on irrigation only, advanced treatment technology for nitrogen, phosphorus removal would not be necessary. The more important point is to be low cost and simple, because most of those who need greywater reuse are low income people.

The Slanted Soil System is one of promising treatment system for this concept. It consists of several chambers containing soil (Fig.1). These chambers are able to be stacked vertically, therefore its footprint is very small (e.g. approximately $1.0 \times 0.5 \mathrm{~m}$ ). This system accepts direct discharge of graywater (Kondo et al. 2011) therefore no pump and no septic tank are required. Itayama et al. (2006) and Kondo et al. (2011) performed continuous monitoring of slanted soil system used by real household in Japan. 
Itayama et al. (2006) reported averaged removal ratio of the COD, the SS, the TN and the $\mathrm{TP}$ as $85 \%, 78 \%, 78 \%$ and $86 \%$. Li et al. (2009) referred this result and concluded that the treated water is not suitable for reuse because it remains high in organic load and suspended solids, which can limit the chemical disinfection. These are however not the discussion for irrigation use but for avoiding eutrophication (Itayama et al. 2006) or for potable reuse ( $\mathrm{Li}$ et al. 2009). Therefore, in this study, we evaluated the performance of the Slanted Soil System as a treatment facility for irrigation reuse, and proposed its design criteria for arid or semi-arid zone.

2. Materials and Methods

2.1. Experimental apparatus and operation

Full scale slanted soil system was installed inside of laboratory; four soil chambers were connected as shown in Fig.2, the size of each chamber was $0.10 \mathrm{~m}$ of depth, $0.145 \mathrm{~m}$ of width, and $0.94 \mathrm{~m}$ of length, chamber bed has gradient of 1/20. We performed 6 cases of experiments, in variety of soil type, soil particle size and amount of discharged wastewater (Table 1). In all experiments, greywater was discharged to first chamber 3 times in a day because actual discharge pattern of greywater shows 2 or 3 peaks in a day (Funamizu et al. 2001, Kondo et al. 2011). In this study, 5 hours intervals were set between 3 discharges; morning, noon and evening. Volume and components of each discharge were listed in Table 1. The volume ratio of kitchen sink wastewater, laundry wastewater and shower wastewater in daily total was fixed at 3:2:5, 
which was determined with referring observed data in developing countries (Ohtaki, 2007; Ushijima, 2007).

Each greywater was prepared synthetically. Kitchen sink wastewater was prepared following the method which was described in detail by Huelgas, 2009. The components listed in Table 2 were well mixed in $5 \mathrm{~L}$ of water solution. After 30 minutes settling, $4 \mathrm{~L}$ of supernatant was diluted with water until 94 L. Incubated Escherichia coli (NBRC13168) and MS2 phage (NBRC 102619) was added to this solution as an indicator of bacterial and virus pathogen respectively. Reported concentrations of $E$. coli in real greywater were $10^{1.2}-10^{5.4} \mathrm{~mL}^{-1}$ (Ottoson and Stenström, 2003) therefore we set the concentration of $E$. coli as $1.0 \times 10^{5} \mathrm{CFU} \mathrm{mL}^{-1}$. Regarding MS2 phage, we set the concentration of $1.0 \times 10^{3} \mathrm{PFU} \mathrm{mL} \mathrm{m}^{-1}$, which is same level as wastewater not separated with toilet wastewater (WHO2006). Laundry wastewater was prepared by washing one new labo apron in automatic laundry machine with $25 \mathrm{~g}$ of laundry detergents. Total water use in the laundry machine was $60 \mathrm{~L}$. Shower waste water was prepared by mixing $5 \mathrm{~g}$ of shampoo, $5 \mathrm{~g}$ of rinse, $5 \mathrm{~g}$ of liquid soap and $3 \mathrm{~g}$ of toothpaste in $30 \mathrm{~L}$ of tap water. Table 3 represents characteristics of synthetic greywater.

Two types of soil were used in this study. Kanuma soil, which was used in the Case 1, consists of alumina and hydrated silica (Itayama et al. 2006). Performance of Kanuma soil had already been examined by previous studies (Kondo et al. 2011, Itayama et al. 2006), however it is very unique soil and available only in Japan. As alternative soil, which is available in the world, crushed baked mud brick was applied in the Case 2 to 6 . It was prepared by crushing baked mud brick and sieving into 1-4 $\mathrm{mm}$ and $4-11 \mathrm{~mm}$. In the Case 4 and 6 , soil in first chamber was replaced with new same 
soil after 3 weeks because clogging was observed at that time. After replacement, experiment was continued under same condition as before replacement.

\subsection{Sampling and analysis}

Effluent of each chamber was sampled every 1 or 2 weeks. Total COD (T-COD), suspended solid (SS), E. coli, and MS2 phage were measured for those samples. Additional to these items dissolved COD (D-COD), biodegradable dissolved organic carbon (BDOC) and liner alkilbenzene sulfonate (LAS) were also measured in the Case 4,5 , and 6 .

COD and suspended solid was measured in standard method of APHA (1985). E. coli in the sample was incubated on "Compact Dry EC (NISSUI PHARMACEUTICAL CO.LTD)" 24 hours under $37^{\circ} \mathrm{C}$, and blue colored E-coli colonies were counted. MS2 phage was measured in PFU method with the double-layer method (Adams, 1959). E. coli (NBRC 13965) is used as bacterial host. Bacteriophage was propagated for 22-24 hours at $37^{\circ} \mathrm{C}$ in E. coli. LAS was measured by liquid chromatography mass spectrometry (LC-MS). Targeted LAS was C10-C14. Eluents was methanol and water, containing ammonium acetate. Solid-phase extraction as the pretreatment for LAS measurement was done using BOND ELUT PPL (500 mg) cartridge. The operation conditions of LC-MS were listed in Table 4. Filtered samples were incubated in BOD bottles at $20^{\circ} \mathrm{C}$ for 7 days and 14 days, and dissolved organic carbon was measured by TOC analyzer (TOC-5000A, Shimazu corp.). Decrease from initial TOC to 7 or 14 days were regarded as $\mathrm{BDOC}_{7}$ and $\mathrm{BDOC}_{14}$ in this study. 
3. Results

\subsection{SS removal and clogging}

SS removal by treatment length was almost linear in logarithmic graph (Fig.3). Total removal rates through 4 chambers were $60-94 \%$, and these were higher in finer particle and lower discharge (Fig.4). Discharged water was overflowed from the chamber due to clogging in the Case $3,4,5$ and 6 at the $5^{\text {th }}, 3^{\text {rd }}, 8^{\text {th }}$ and $3^{\text {rd }}$ week, respectively. Time periods until clogging $(\mathrm{T})$ were longer in coarser soil and higher discharge. In the Case 5, combination of fine and coarse soil, $\mathrm{T}$ was longer than those using fine soil only (Case 3, 4, and 6). However, no relationship was observed between $\mathrm{T}$ and estimated cumulative amount of SS removal.

3.2. Removal of organic materials and LAS

T-COD at the outlet of $4^{\text {th }}$ chamber on $4^{\text {th }}$ week were $154-394 \mathrm{mg} \mathrm{L}^{-1}$, while the results of Case 4 and 6 were at $2^{\text {nd }}$ week because these were clogged at $3^{\text {rd }}$ week. The removal rates (Fig.5) were 52-83\%, higher in finer particle and lower discharge. In the Case 4, 5, and 6, those measured D-COD and BDOC, more than 90\% of particle COD (P-COD), derived by deducting D-COD from T-COD, was removed by this system (Fig.6). Although the removal rates of D-COD were lower (58-68\%), those of both $\mathrm{BDOC}_{7}$ and $\mathrm{BDOC}_{14}$ were removed $87-91 \%$ (Fig.6). This is probably because 
biologically degradable organic matters in dissolved part were selectively removed and non-degradable or less degradable matters remained.

LAS at the outlet of $4^{\text {th }}$ chamber on $3^{\text {rd }}$ week (the case 4 and 6 ) or $4^{\text {th }}$ week (the case 5) were 2.3-3.3 $\mathrm{mg} \mathrm{L}^{-1}$, and removal rates were 93-96\%.

\subsection{Pathogens removal}

Fig. 7 and Fig. 8 show E. coli and MS2 phage concentrations in each case, respectively. Most of E. coli and MS2 phage were not removed in all chambers containing coarse soil; the Case 1 and 2 and $1^{\text {st }}$ chamber of Case 5 . In contrast to those using coarse soil, $5 \log _{10}$ reduction of $E$. coli and $3 \log _{10}$ reduction of MS2 phage were performed through one or two chambers until $3^{\text {rd }}$ or $4^{\text {th }}$ week, in the Case $3,4,5$, and 6 , those used fine soil. After $4^{\text {th }}$ or $5^{\text {th }}$ week, breakthrough of E. coli and MS2 were observed in the Case 3 and 5. No breakthrough was observed in the Case 4 and 6 , probably because experimental periods were only 3 weeks.

\section{Discussion}

\subsection{Treatment performance}

Fine soil presented better removal performance of pathogen, SS, and T-COD. Particularly, sufficient pathogen removals were performed only by fine soil chamber, while most part of pathogen passed through coarse soil chamber. Disadvantage of fine 
soil was shorter time periods until clog, however result of the Case 5 represented that combination of coarse and fine soil can extend this time period to more than double. Most of previous studies used Kanuma soil, which is generally $10 \mathrm{~mm}$ or larger particle size (Itayama et al. 2006). Clogging was not observed in these previous studies (e.g. Itayama et al. 2006, Kondo et al. 2001), however they did not measure pathogens. Tada et al. (2007) used combination of several local soils; pumiceous soil $(4-20 \mathrm{~mm})$ for $1^{\text {st }}$ and $2^{\text {nd }}$ chambers, river sand $(0.5-4 \mathrm{~mm})$ for $3^{\text {rd }}$ chamber, and limestone soil $(0.25-2$ $\mathrm{mm}$ ) for $4^{\text {th }}$ chamber, and its time period until clogging was half year. Two of coarse soil chambers $(2 \mathrm{~m})$, and too low $q\left(0.06-0.36 \mathrm{~m}^{3} \mathrm{~m}^{-2} \mathrm{~d}^{-1}\right.$, which is $1 / 10-1 / 50$ of our experiment) probably caused this longer period until clogging than our results.

Originally, slanted soil chamber system was developed to reduce environmental impact, and therefore focus of the previous studies was removal rate of organic matter and nutrients (Itayama et al. 2006; Kondo et al. 2011; Tada et al. 2007). In light of required water quality for irrigation reuse, removal of nutrient is not so important but removal of organic matters is important because they cause clogging of irrigation facilities such as drip irrigation system, and therefore particle COD (P-COD) and BDOC would be especially important. Fig.6 implies that the slanted soil system in this study performed high removal rate in both P-COD (94-97\%) and BDOC (88-89\%), while removal rate of D-COD (58-68\%) was comparatively low. Although BDOC levels in treated water (11-12 $\left.\mathrm{mg} \mathrm{L}^{-1}\right)$ were much lower than untreated greywater, these exceed $0.15-0.25 \mathrm{mg} \mathrm{L}^{-1}$ those were reported as maximum level to avoid bacterial regrowth (Servais et al. 1995; Niquette et al. 2001). Of course the volume of biofilm 
and increasing speed of biofilm volume are supposed to become smaller than untreated greywater, however farther practical study is needed for quantitative evaluation.

LAS removal rates were more than $90 \%$ and final concentrations (2.3-3.3 $\left.\mathrm{mg} \mathrm{L}^{-1}\right)$ were sufficiently lower than $8 \mathrm{mgL}^{-1}$ which was proposed as target level for irrigation use (Hijikata et al.2011). However, this study could not cover byproduct of LAS degradation, which was found in treated greywater by another system (Huelgus, 2009). Direct toxicity assessment, such as germination test or plant growth test will give farther information about this issue.

\subsection{Reduction characteristics of COD and LAS}

Reduction curves of T-COD against chamber length seem linear in logarithmic graph (Fig.9). When we assume uniform flow velocity inside of each system, these reductions can be regarded as first order kinetic reaction, which is described as

$$
C_{C O D}=C_{O C O D} \cdot \exp \left(-k_{C O D} L\right)
$$

where $C_{C O D}$ is COD concentration, $C_{O C O D}$ is initial concentration, $k_{C O D}$ is the reaction coefficient with $\mathrm{m}^{-1}$ unit and $L$ is length of soil (Table 5). Because of the assumption above, the $k_{C O D}$ values would change by different flow velocity. Therefore, correlations between $k_{C O D}$ and possible control factors of flow velocity; elapsed time, soil particle size and $q$ defined by $Q /(W \times D)$ where $Q$ is daily discharge $\left(\mathrm{m}^{3} \mathrm{~d}^{-1}\right), W$ is width of chamber, and $D$ is depth of chamber, were accessed. Slope of chamber bed also affects 
flow velocity, but in this study it was fixed at $1 / 20$. As s result, $k_{T-C O D}$ shows linear correlation with $q$ in the equation of

$$
k_{T-C O D}=-0.04 q+0.5
$$

by high correlation coefficient $\left(\mathrm{R}^{2}=0.87\right)$ but other factors does not show clear correlation.

As well as T-COD, first order kinetic reaction equation by length was applied for LAS reduction curve (Fig.10).

$$
C_{L A S}=C_{O L A S} \cdot \exp \left(-k_{L A S} L\right)
$$

where $C_{L A S}$ is LAS concentration, $C_{O L A S}$ is initial concentration, $k_{L A S}$ is the reaction coefficient with $\mathrm{m}^{-1}$ unit. $k_{\text {LAS }}$ of the Case 4,5 , and 6 were $0.73\left(\mathrm{R}^{2}=0.92\right), 0.73$ $\left(\mathrm{R}^{2}=0.91\right)$, and $0.76\left(\mathrm{R}^{2}=0.83\right)$, respectively. $k_{L A S}$ shows linear correlation with $q$ in the equation of

$$
k_{L A S}=-0.02 q+0.8
$$

by high correlation coefficient $\left(\mathrm{R}^{2}=0.99\right)$, but other factors does not show clear correlation.

\subsection{Design criteria}


First of all, fine soil chamber is required in order to remove pathogen. According to the results of the Case 3 and 5, those observed breakthrough, removal capacity levels of $E$. coli and MS2 phage in one chamber $(0.145 \mathrm{~m}$ width, $0.1 \mathrm{~m}$ height, and $0.94 \mathrm{~m}$ length) were estimated $10^{10} \mathrm{CFU}$ and $10^{8} \mathrm{PFU}$, respectively. When the capacity became full, it has to be replaced. Required replacement interval (INT) would be explained by

$$
I N T=6.9 q^{-1}[\mathrm{~d}] .
$$

On the other hand, outlet concentrations of LAS are able to simulate by equation (3) and (4). In case applying target level of $8 \mathrm{mgL}^{-1}$ proposed by Hijikata et al. (2011), adequate $q$ which satisfies $C_{L A S}<8$ have to be set. Regarding organic matters, farther study is required in order to simulate outlet concentration, not only of T-COD but also of P-COD and BDOC. The $q$ is determined by balance between chamber size and discharged volume of greywater, and therefore possible chamber size can be designed according to expected discharged volume.

Regarding clogging issue, combination of coarse and fine soil is preferable. According to result of the Case 5, first 1 or 2 chambers were recommended to use coarse soil, and it extends time periods until clogging. Under the condition of Case 5, time period until clogging was longer than $D$, however quantitative evaluation on clogging under different condition is difficult so far.

\section{Conclusions}


Performance of the slanted soil system for greywater was evaluated in light of required water quality for irrigation reuse. The slanted soil system performed high removal rate in both P-COD (94-97\%) and BDOC (88-89\%), while removal rate of DCOD (58-68\%) was comparatively low. LAS removal rates were more than $90 \%$ and final concentrations $\left(2.3-3.3 \mathrm{mgL}^{-1}\right)$ were sufficiently lower than $8 \mathrm{mgL}^{-1}$ which was proposed as target level for irrigation use (Hijikata et al. 2011). First order reaction equation of T-COD and LAS were determined and $k_{T-C O D}$ and $k_{L A S}$ were expressed by the equation of $q$. Fine soil (1-4 $\mathrm{mm}$ ) presented better removal performance of pathogen, SS, and T-COD than coarse soil (4-11mm). Particularly, sufficient pathogen removals were performed only by fine soil chamber, while most part of pathogen passed through coarse soil chamber. Disadvantage of fine soil was recognized in shorter time periods until clog, however result of the Case 5 represented that combination of coarse and fine soil can extend this time period.

\section{Acknowledgement}

This research was supported by JST-CREST, JST-JICA and JSPS-Science Research (type S).

\section{References}

Adams, M.H., 1959. Bacteriophages, Interscience Publishers, New York. 
APHA, 1985. Standard Method for the Environment of Water and Wastewater, 16th edition, American Public Health Association, Washington, D.C.

Asano, T., Burton, F.L., Leverenz, H.L., Tsuchihashi, R., Tchobanoglous, G., 2007. Water Reuse, issues, technologies and application, Metcalf \& Eddy, Inc. an AECOM Company, New York.

Gajurel, D.R., Li, Z., Otterpohl, R., 2003. Investigation of the effectiveness of source control sanitation concepts including pre-treatment with Rottebehaelter, Wat. Sci. Tech. 41, 111-118.

Garland, J.L., Levine, L.H., Yorio, N.C., Adams, J.L. and Hummerick, M.E., 2004. Response of greywater recycling systems based on hydroponic plant growth to three classes of surfactants, Wat. Res. 38, 1952-1962.

Hijikata, N., Nakaoka, E., Sawadogo, B., Ushijiam, K., Funamizu, N., 2011. Phytotoxicity assay of several gray waters for reuse as agricultural irrigation, Proceedings of the IWA International conference Cities of the Future Xi'an. Xi'an, China (CD-ROM).

Huelgas, A. P., 2009. Onsite Treatment of Higher-load Graywater by Membrane Bioreactor, Dissertation for the Doctoral Degree. Hokkaido University, Sapporo. Itayama, T., Kiji, M., Suetugu, A., Tanaka, N., Saito, T., Iwami, N., Mizuochi, M., Inamori, Y., 2006. On site experiments of the slanted soil treatment systems for domestic gray water, Wat. Sci. Tech. 53, 193-201.

Kondo, T., Ebie, Y., Kiji, M., Sugiura, N., Xu, K., Inamori, Y., 2011. Decentralized domestic gray water treatment by using slanted soil chamber system, Sustain. Environ. Res. 21, 81-87. 
Lal, R., 1998. Soil erosion impact on agricultural productivity and environmental quality. Critical Reviews in Plant Sci. 17, 319- 464.

Li, F., Wichmann, K., Otterpohl, R., 2009. Review of the technological approaches for grey water treatment and reuses, Science of the Total Environment, 407, 3439-3449.

Lopez Zavala, M.A., Funamizu, N., Takakuwa, T., 2002. Onsite wastewater differentiable treatment system: modelling approach, Wat. Sci. Tech. 46, 317324.

Otaki, M., 2007. Water use in Thailand, J. human env. Eng. 9, 124-127. (in Japanese)

Ottoson, J., Stenström, T.A., 2003. Faecal contamination of greywater and associated microbial risks, Wat. Res. 37, 645-655.

Raschid-Sally, L., Jayakody, P., 2008. Drivers and characteristics of wastewater agriculture in developing countries - results from a global assessment, International Wastewater Management Institute, Colombo.

Tada, C., Itayama, T., Iwami, N., Kuwabara, T., Tanaka, N., Ebie, Y., Inamori, Y., Ushijima, K., Moritani, A., 2007. Characteristics of kitchen wastewater treatment by slanted soil treatment system using various soils, Proceedings of the $5^{\text {th }}$ International Symposium on Sustainable Sanitation, Tokyo, Japan, pp.101-107.

Ushijima, K., Irie, M., Sintawardani, N., Triastuti, J., Ishikawa, T., 2008. Field research on domestic wastewater from a slum in Bandung City, J. Hydroscience and Hydraulic Eng. 26, 129-140. 
Ushijima, K., Hijikata, N., Ito, R., Funamizu, N., 2011, Effect Estimation of Dry-Toilet Application for Rural Farmer Family in Burkina Faso, J. Arid Land Studies. (in press)

Visser S.M., Stroosnijder, L., Chardon, W.J. 2005. Nutrient losses by wind and water measurements and modelling, Catena 63, 1-22.

World Health Organization, 2006. WHO guidelines for the safe use of wastewater, excreta and greywater, vol.2, wastewatere use in agriculture, WHO publication, Geneva. 


\section{Table 1}

Variation of greywater discharge, experimental period and soil type.

\begin{tabular}{|c|c|c|c|c|c|}
\hline & & Greywater discharge & $\begin{array}{l}\text { Total } \\
\text { discharge }\end{array}$ & $\begin{array}{l}\text { Experimental } \\
\text { period }\end{array}$ & Soil type \\
\hline Case 1 & $\begin{array}{l}\text { Morning } \\
\text { Noon } \\
\text { Evening }\end{array}$ & $\begin{array}{l}\text { KSWW 6L + LWW 12L } \\
\text { KSWW 6L } \\
\text { KSWW 6L + SWW 30L }\end{array}$ & $60 \mathrm{~L} / \mathrm{d}$ & 6 weeks & $\begin{array}{l}\text { Kanuma soil } \\
\text { (4-11 mm) }\end{array}$ \\
\hline Case 2 & $\begin{array}{l}\text { Morning } \\
\text { Noon } \\
\text { Evening }\end{array}$ & $\begin{array}{l}\text { KSWW 6L + LWW 12L } \\
\text { KSWW 6L } \\
\text { KSWW 6L + SWW 30L }\end{array}$ & $60 \mathrm{~L} / \mathrm{d}$ & 6 weeks & $\begin{array}{l}\text { Crushed baked mud brick } \\
(4-11 \mathrm{~mm})\end{array}$ \\
\hline Case 3 & $\begin{array}{l}\text { Morning } \\
\text { Noon } \\
\text { Evening }\end{array}$ & $\begin{array}{l}\text { KSWW 6L + LWW 12L } \\
\text { KSWW 6L } \\
\text { KSWW 6L + SWW 30L }\end{array}$ & $60 \mathrm{~L} / \mathrm{d}$ & 5 weeks $*$ & $\begin{array}{l}\text { Crushed baked mud brick } \\
(1-4 \mathrm{~mm})\end{array}$ \\
\hline Case 4 & $\begin{array}{l}\text { Morning } \\
\text { Noon } \\
\text { Evening }\end{array}$ & $\begin{array}{l}\text { KSWW 3L + LWW 6L } \\
\text { KSWW 3L } \\
\text { KSWW 3L + SWW 15L }\end{array}$ & $30 \mathrm{~L} / \mathrm{d}$ & 8 weeks $* *$ & $\begin{array}{l}\text { Crushed baked mud brick } \\
(1-4 \mathrm{~mm})\end{array}$ \\
\hline Case 5 & $\begin{array}{l}\text { Morning } \\
\text { Noon } \\
\text { Evening }\end{array}$ & $\begin{array}{l}\text { KSWW 3L + LWW 6L } \\
\text { KSWW 3L } \\
\text { KSWW 3L + SWW 15L }\end{array}$ & $30 \mathrm{~L} / \mathrm{d}$ & 8 weeks $* * *$ & $\begin{array}{l}\text { Crushed baked mud brick } \\
\left(1^{\text {st }} \text { chamber } 1-4 \mathrm{~mm} \text {, }\right. \\
\left.2^{\text {nd }}-4^{\text {th }} \text { chamber } 4-11 \mathrm{~mm}\right)\end{array}$ \\
\hline Case 6 & $\begin{array}{l}\text { Morning } \\
\text { Noon } \\
\text { Evening }\end{array}$ & $\begin{array}{l}\text { KSWW 1.5L + LWW 3L } \\
\text { KSWW 1.5L } \\
\text { KSWW 1.5L + SWW 7.5L }\end{array}$ & $15 \mathrm{~L} / \mathrm{d}$ & 8 weeks $* *$ & $\begin{array}{l}\text { Crushed baked mud brick } \\
(1-4 \mathrm{~mm})\end{array}$ \\
\hline
\end{tabular}

KSWW: kitchen sink waste water, LWW: Laundry waste water, SWW: shower waste water

* Experiment was ended at $5^{\text {th }}$ week because overflow due to clogging was observed.

** The soil in $1^{\text {st }}$ chamber was replaced by new soil at $3^{\text {rd }}$ week, when overflow was observed.

*** Experiment was ended at $8^{\text {th }}$ week because overflow due to clogging was observed.. 


\section{Table 2}

Components of synthetic kitchen sink waste water.

\begin{tabular}{lc}
\hline Components & Amount \\
\hline Kitchen detergents & $5.12 \mathrm{~g}$ \\
Soybean flower & $34.6 \mathrm{~g}$ \\
Fish powder & $34.6 \mathrm{~g}$ \\
Dextrine & $6.9 \mathrm{~g}$ \\
Powder cream for coffee & $21.6 \mathrm{~g}$ \\
Beef extract & $5.2 \mathrm{~g}$ \\
Carrot & $34.6 \mathrm{~g}$ \\
Cabage & $34.6 \mathrm{~g}$ \\
Banana peel & $25.9 \mathrm{~g}$ \\
Apple & $25.9 \mathrm{~g}$ \\
Grapefruit peel & $25.9 \mathrm{~g}$ \\
Dried horse mackerel & $25.9 \mathrm{~g}$ \\
Cooked rice & $25.9 \mathrm{~g}$ \\
Tea leaves & $7.6 \mathrm{~g}$ \\
\hline
\end{tabular}


Table 3

Characteristics of each greywater.

\begin{tabular}{lrrr}
\hline & KSWW & LWW & \multicolumn{1}{c}{ SWW } \\
\hline T-COD (mg/L) & $600-1,000$ & $500-600$ & $200-400$ \\
SS (mg/L) & $150-250$ & $70-100$ & $40-70$ \\
pH & 7.0 & 10.1 & 7.3 \\
EC (mS/cm) & 0.69 & 1.15 & 0.28 \\
E. coli (CFU/mL) & $10^{5}$ & - & - \\
MS2 phage (PFU/mL) & $10^{3}$ & - & - \\
LAS (mg/L) & - & 50 & - \\
\hline
\end{tabular}


Table 4

Operation condition of LCMS for LAS measurement.

\begin{tabular}{ll}
\hline Items & condition \\
\hline Column & Wakopak WS AS-Aqua $(4.6 \times 250 \mathrm{~mm})$ \\
Mobile phase & A) $0.2 \mathrm{mM}$ ammonium acetate in acetonitrile \\
& B) $0.2 \mathrm{mM}$ ammonium acetate in water \\
Flow rate & $0.25 \mathrm{ml} / \mathrm{min}$ \\
Injection volume & $10 \mu 1$ \\
Ionization method & $\mathrm{ESI}($ electrospray ionization $)$ \\
Measurement mode & negative \\
Capillary voltage & $4.5 \mathrm{kV}$ \\
Drying gas temperature & $350^{\circ} \mathrm{C}$ \\
Column Temperature & $40^{\circ} \mathrm{C}$ \\
\hline
\end{tabular}




\section{Table 5}

Reaction coefficient $k$ for T-COD reduction.

\begin{tabular}{ccc}
\hline & Reaction coefficient $k$ & $\mathrm{R}^{2}$ \\
\hline Case 1 & 0.194 & 0.99 \\
Case 2 & 0.213 & 0.96 \\
Case 3 & 0.342 & 0.96 \\
Case 4 & 0.388 & 0.98 \\
Case 5 & 0.466 & 0.99 \\
Case 6 & 0.475 & 0.98 \\
\hline
\end{tabular}


Fig.1 Structure of slanted soil system.

Fig.2 Picture of slanted soil system for this experiment.

Fig.3 Concentration of suspended solid (SS) at influent and effluent from each chamber on $4^{\text {th }}$ week (the Case $1,2,3$, and 5) and $2^{\text {nd }}$ week (the Case 4 and 6).

Fig.4 Removal rate of suspended solid (SS) at the outlet of $4^{\text {th }}$ chamber on $4^{\text {th }}$ week (the Case 1, 2, 3, and 5) and $2^{\text {nd }}$ week (the Case 4 and 6).

Fig.5 Total COD (T-COD) removal rate at the outlet of 4 th chamber on $4^{\text {th }}$ week (the Case 1, 2, 3, and 5) and $2^{\text {nd }}$ week (the Case 4 and 6).

Fig.6 Removal rate of particle COD (P-COD), dissolved COD (D-COD), and biodegradable dissolved organic carbon upon 7 days incubation $\left(\mathrm{BDOC}_{7}\right)$ and 14 days incubation $\left(\mathrm{BDOC}_{14}\right)$.

Fig.7 E. coli concentration at influent and effluent from each chamber.

Fig.8 MS2 phage concentration at influent and effluent from each chamber.

Fig.9 Concentration of total COD (T-COD) at influent and effluent from each chamber on $4^{\text {th }}$ week (the Case $1,2,3$, and 5) and $2^{\text {nd }}$ week (the Case 4 and 6).

Fig.10 Concentration of liner alkilbenzene sulfonate (LAS) at influent and effluent from each chamber on $4^{\text {th }}$ week (the Case 5) and $2^{\text {nd }}$ week (the Case 4 and 6). 


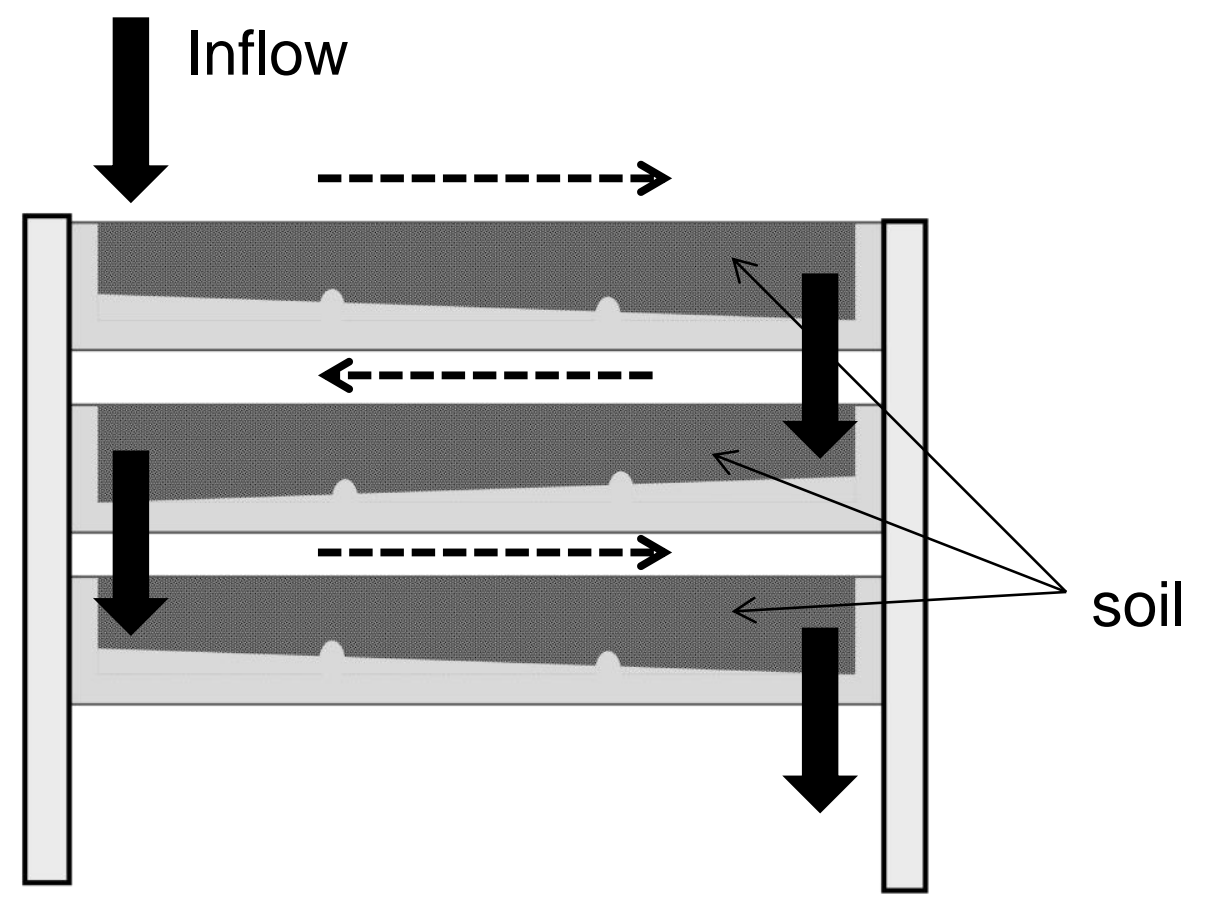




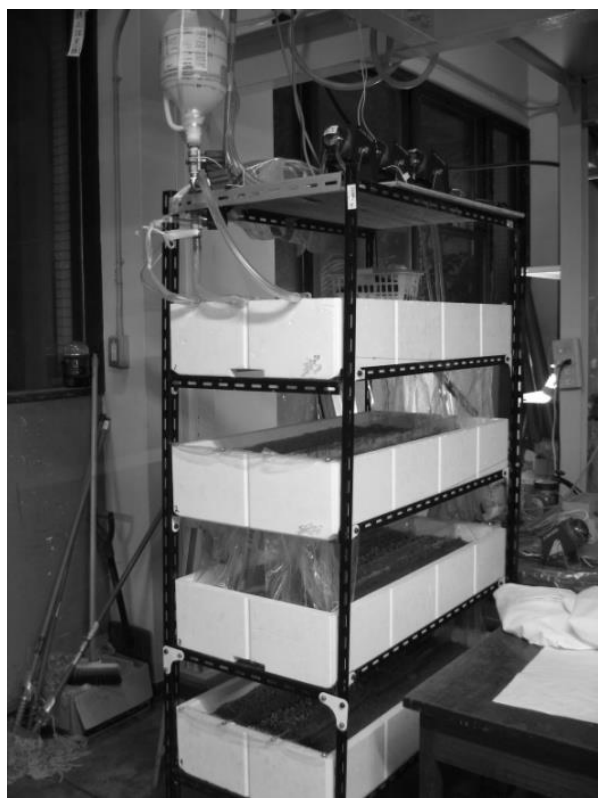




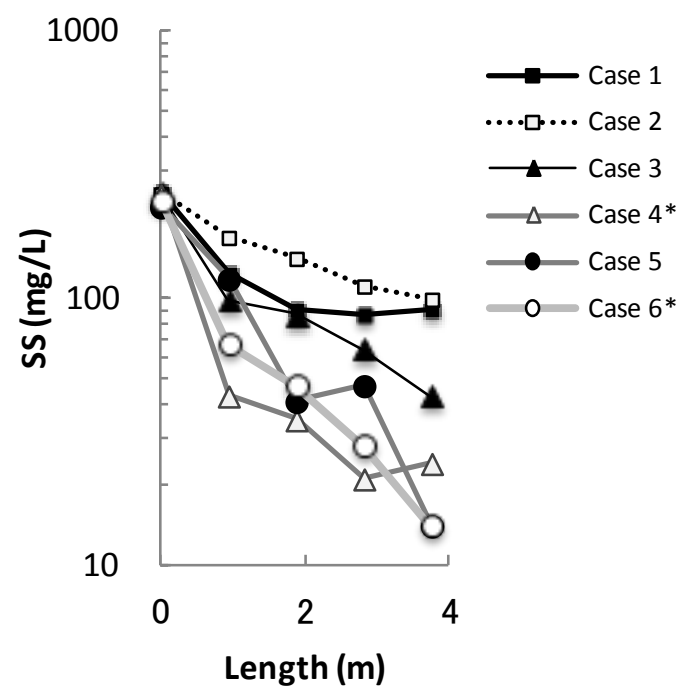




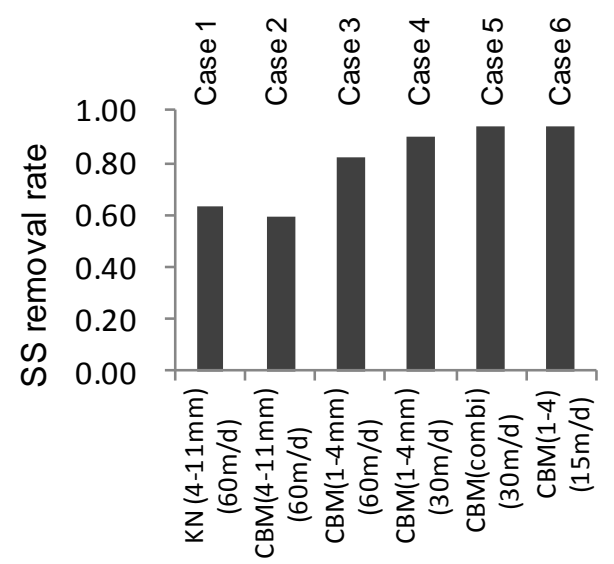




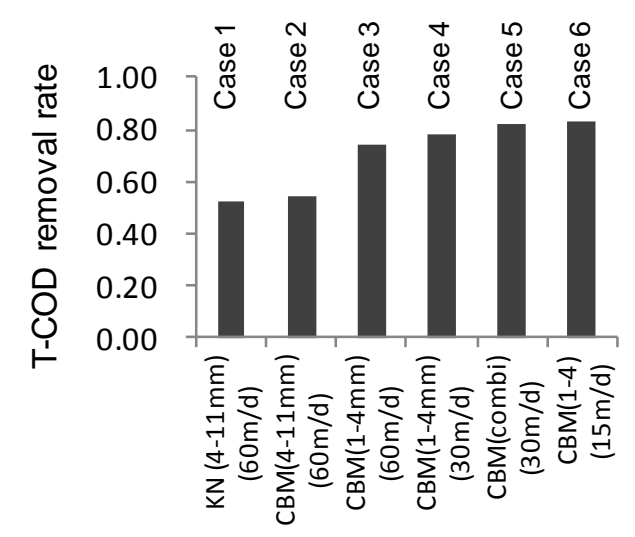




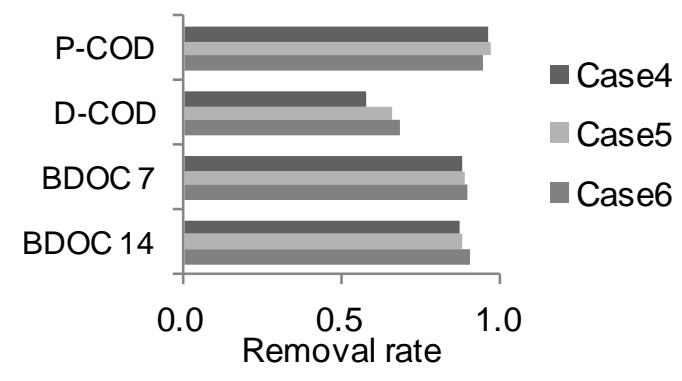



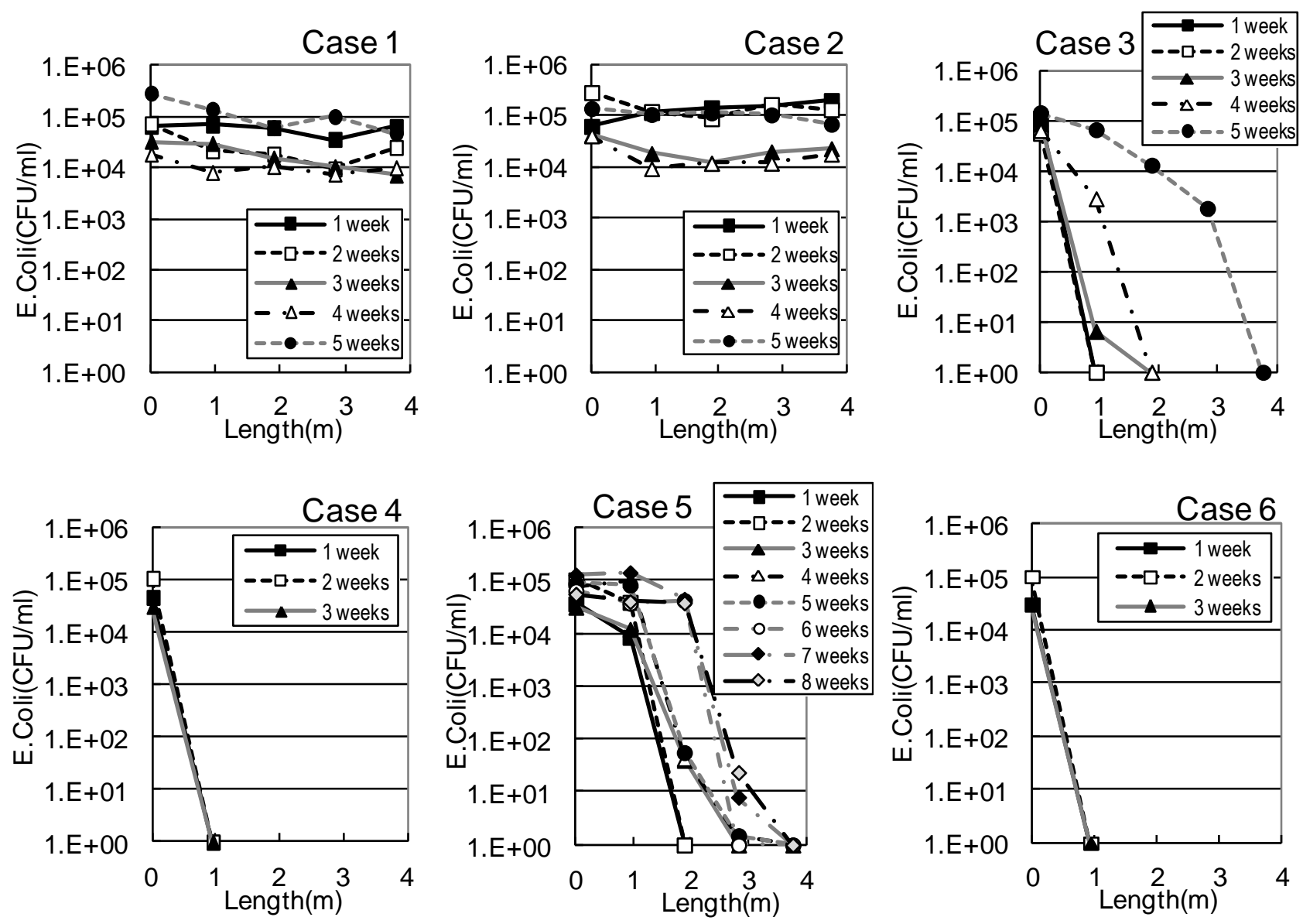
Case 1
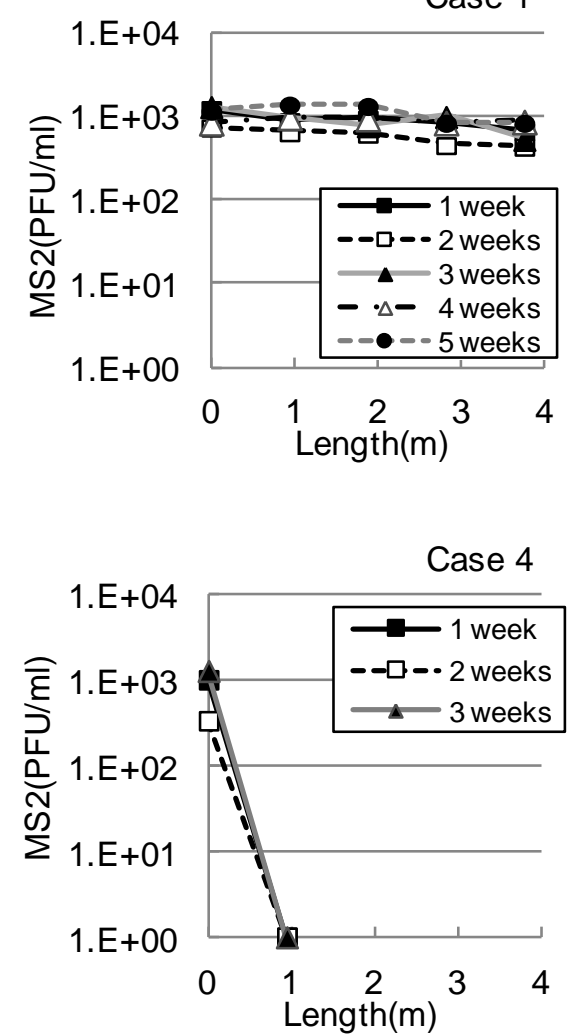

Case 2
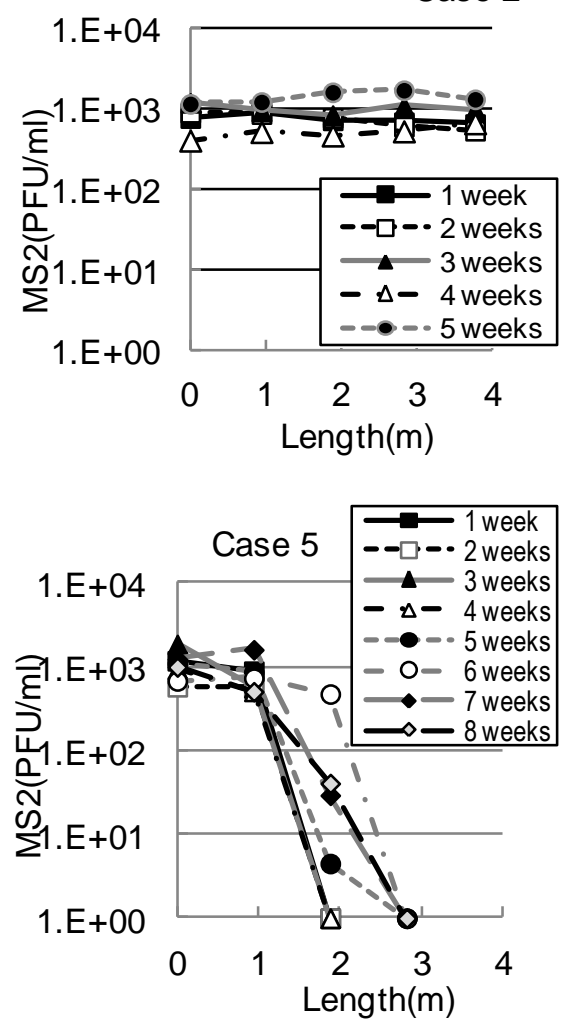

Case 3
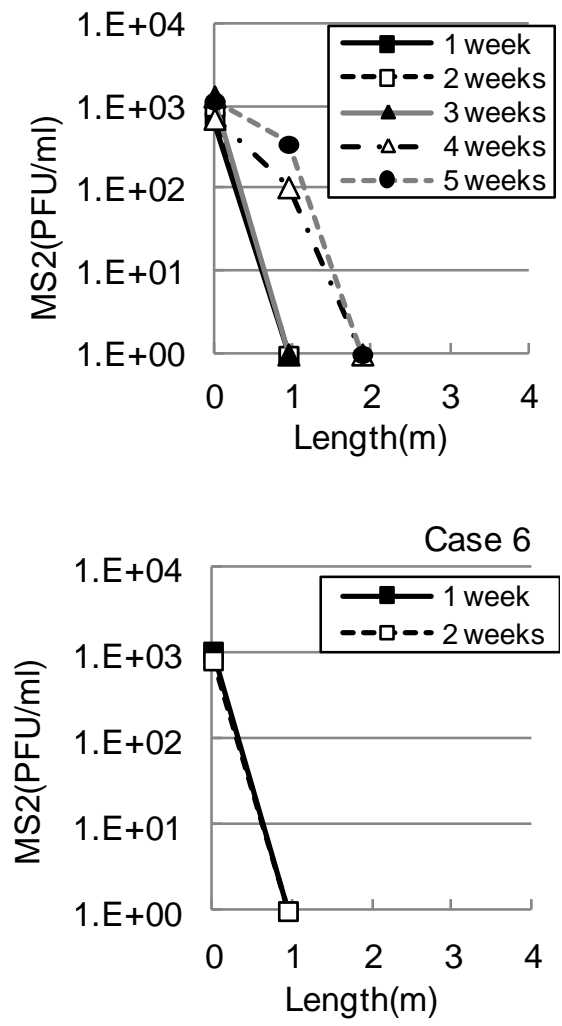


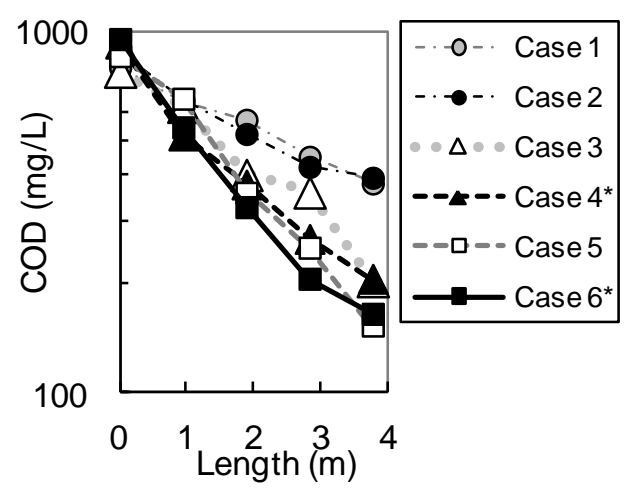




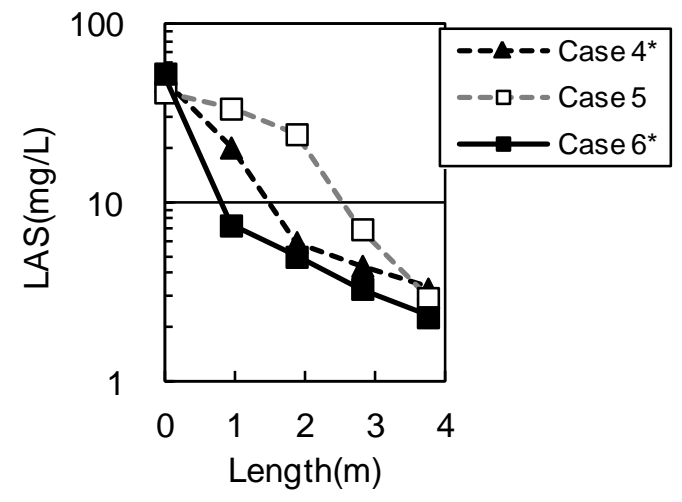

